\title{
Evaluation of cation-anion diets in calcium metabolism in ruminants
}

\author{
Ana Alix Mendes de Almeida Oliveira1, Dorinha Miriam Silber Schmidt Vitti' ${ }^{2}$, Simone \\ Raymundo de Oliveira ${ }^{3}$, Patrícia Barcellos Costa ${ }^{1}$, Marcela Abbado Neres ${ }^{1}$, Paula Regina \\ Hermes $^{1}$, Cristiani Cavilhão', Paula Konieczniak ${ }^{1}$
}

\footnotetext{
${ }^{1}$ Universidade Estadual do Oeste do Paraná, Marechal Cândido Rondon, PR, Brasil

2 Universidade de São Paulo, Centro de Energia Nuclear na Agricultura, Piracicaba, SP, Brasil.

${ }^{3}$ Agência Paulista de Tecnologia dos Agronegócios, Piracicaba, SP, Brasil.
}

\begin{abstract}
The objective of this study was to evaluate the use of the dietary cation-anion balance (DCAB) on the calcium metabolism in male Nellore steers with a mean age of 10 months. Three experimental diets were tested: a cationic diet, a diet consisting of Tifton hay only, and an anionic diet with $+15.2,+23.9$ and $-10.0 \mathrm{mEq} / 100 \mathrm{~g}$ DM of DCAB values in the diet. The anionic diet was calculated as the addition of salts of ammonium chloride and magnesium sulfate. Based on the isotope dilution technique, the negative DCAB value used in this study $(-10.0 \mathrm{mEq} / 100 \mathrm{~g} \mathrm{DM})$ does not affect calcium metabolism, especially endogenous losses and true absorption.
\end{abstract}

Key Words: cattle, feeds, isotopes, mineral metabolism

\section{Introduction}

The dietary cation-anion balance (DCAB) is a subject of interest in nutrition because it can positively influence both the animal production and environmental pollution rates.

The dietary cation-anion balance can be defined as the balance between the concentration in milliequivalents $(\mathrm{mEq})$ of cations and anions in the diet, i.e., the sum of total fixed cations of sodium $(\mathrm{Na})$ and potassium $(\mathrm{K})$ minus the total fixed anions of chlorine $(\mathrm{Cl})$ and sulfur (S): $[(\mathrm{Na}+\mathrm{K})-(\mathrm{Cl}+\mathrm{S})] / 100 \mathrm{~g} \mathrm{DM}$ (Dishington, 1975). An anionic diet is considered when results of calculations of DCAB are between -100 and $-200 \mathrm{mEq} / \mathrm{g} \mathrm{DM}$. For ruminants, the negative $\mathrm{DCAB}$ has reduced the incidence of parturient paresis; when animals consume cationic diets, the metabolism of this mineral is changed. Cells of target tissues (kidney and bone) lose their sensitivity to parathyroid hormone (PTH) and then there is no bone or renal resorption. The use of anionic diets restores the sensitivity of cells to PTH and homeostatic calcium levels in blood (Schonewille et al., 1994; Setti et al., 1998).

Horst et al. (1994) confirmed the possible action mechanisms of anionic diets on the balance of minerals.

Received May 21, 2014 and accepted August 25, 2014.

Corresponding author: analix68@hotmail.com

http://dx.doi.org/10.1590/S1516-35982014001100006

Copyright (C) 2014 Sociedade Brasileira de Zootecnia. This is an Open Access article distributed under the terms of the Creative Commons Attribution Non-Commercial License, which permits unrestricted non-commercial use, distribution, and reproduction in any medium, provided the original work is properly cited.
The addition of anions $(-25.0 \mathrm{mEq} / 100 \mathrm{~g} \mathrm{DM})$ to diets could increase the osteoclastic activity of bone resorption in addition to promoting an increase in the $1,25(\mathrm{OH})_{2} \mathrm{D}$ biosynthesis in cattle.

With respect to production rates, it is believed that the DCAB may contribute to the daily weight gain (DWG) and feed conversion of beef cattle. Ross et al. (1994) reported better results for DWG when supplying diets with positive DCAB values (15-30 mEq/100 g DM). Spears (1996) outlined advantages of using DCAB in diets for beef cattle as one of the possible solutions to increase the total DM intake and DWG. Hersom et al. (2010) investigated the hypothesis that forages with negative DCAB values would affect dry matter intake, acid-base physiology and uterine $\mathrm{pH}$ in beef cows. Neither initial nor final cow body weight was different between high and low DCAB.

A diet can be manipulated to change the acid-base balance in the organism of domestic animals. Salles et al. (2012) studied the influence of different DCAB levels and their relationship with the proportions of dietary roughage $(60-40 \%)$ and concentrate $(40-60 \%)$ on the metabolism of growing weaned Holstein calves fed diets with -100 , +200 and $+400 \mathrm{mEq} / \mathrm{kg}$ of DM. A linear increase following increased dietary cation-anion balance was observed on bicarbonate concentration, carbon dioxide tension, carbon dioxide partial pressure and urine $\mathrm{pH}$. Growing-ruminant metabolism both in cationic and anionic diets was modified.

It is believed that the bioavailability of calcium and phosphorus can be changed according to changes in the levels of cations and anions in the diet. The regulatory 
mechanisms in the kidney and bone tissue, responsible for urinary excretion of calcium and phosphorus and bone resorption, are also affected by cation-anion diets (Abu Damir et al., 1991).

Given the scarcity of studies to clarify the mechanisms of the calcium metabolism, altered by the use of DCAB, this research aimed to evaluate possible differences in the actual calcium absorption in beef cattle, its endogenous levels and its bioavailability.

\section{Material and Methods}

The research was conducted in Animal Laboratory located in Piracicaba city/SP, Brazil. The geographic coordinates are $22^{\circ} 25^{\prime} \mathrm{S}$ (latitude) and $47^{\circ} 22^{\prime} \mathrm{W}$ (longitude) and altitude of $580 \mathrm{~m}$. Piracicaba has a CWa climate, according to Köppen.

Twelve male Nellore steers with a mean age of 10 months and weight of $180 \mathrm{~kg}$ were used in a randomized block design with three DCAB values $(+15.2,+23.9$ and $-10.0 \mathrm{mEq} / 100 \mathrm{~g} \mathrm{DM}$ ) and two blocks with four replications in time. Three experimental diets were prepared containing DCAB values. The cationic (CAT) and anionic (ANI) diets had proximal levels concerning the chemical composition in total digestible nutrients
(TDN), crude protein (CP), calcium (Ca) and phosphorus (P) according to the NRC recommendations (1996). The TFT diet that was composed exclusively of Tifton hay, represented the practical conditions of animals raised in the field, with metabolic profile of diets based on forages rich in cations but poor in $\mathrm{Ca}$ and $\mathrm{P}$; thus, it was possible to observe and compare values of endogenous levels, true absorption and excretion of $\mathrm{Ca}$ and $\mathrm{P}$ in animals subjected to a condition of mineral deficiency and consequently in negative balance.

The tested diets were: a cationic diet (CAT) based on Tifton hay and cationic concentrate, containing corn and soybean meal; a forage diet (TFT) consisting of Tifton hay only; and an anionic diet (ANI) based on Tifton hay plus anionic concentrate, containing corn plus soybean meal, supplemented with magnesium sulfate and ammonium chloride (Tables 1 and 2).

The dietary cation-anion balance (DCAB) was calculated using the following expression: $\mathrm{mEq}[\mathrm{Na}+\mathrm{K}$ ) $-(\mathrm{Cl}+\mathrm{S})] / 100 \mathrm{~g} \mathrm{DM}$ of the diet, described by Dishington (1975) (Table 3). Chemical analyses were performed on the diets for their nutritive values, according to the recommendations of AOAC (1980) concerning levels of phosphorus (colorimetry) and calcium (atomic absorption spectrometry).

Table 1 - Percentage composition of experimental diets

\begin{tabular}{|c|c|c|c|}
\hline \multirow[b]{2}{*}{ Ingredients } & \multicolumn{3}{|c|}{$\%$ Diet } \\
\hline & $\begin{array}{c}\text { Cationic diet } \\
\text { Hay }+ \text { cationic concentrate }\end{array}$ & $\begin{array}{c}\text { Forage diet } \\
\text { Hay (no concentrate) }\end{array}$ & $\begin{array}{c}\text { Anionic diet } \\
\text { Hay }+ \text { anionic concentrate }\end{array}$ \\
\hline Tifton hay & 54.4 & 100.0 & 54.67 \\
\hline Corn & 33.23 & - & 37.02 \\
\hline Soybean meal & 10.01 & - & 4.55 \\
\hline Ammonium chloride & - & - & 0.91 \\
\hline Total & 100.0 & 100.0 & 100.0 \\
\hline
\end{tabular}

${ }^{1}$ Vitamin-mineral mix: composition of trace elements (in ppm) Mn - 1,450; Zn - 1,900; Fe - 500; Cu - 450; Co - 10 ppm; I - 25; Se - 11.5; monensin - 920; composition of vitamins (in IU/kg product): vit. A - 100,000; vit. D - 25,000; vit. E - 1,000.

Table 2 - Chemical composition of cationic concentrate, Tifton hay and anionic concentrate

\begin{tabular}{lccc}
\hline Chemical composition & Cationic concentrate & Tifton hay & Anionic concentrate \\
\hline Dry matter $(\mathrm{g} / \mathrm{kg})$ & 910.90 & 933.60 & 901.40 \\
Mineral matter $(\mathrm{g} / \mathrm{kg} \mathrm{DM})$ & 52.40 & 63.0 & 55.10 \\
Ether extract $(\mathrm{g} / \mathrm{kg} \mathrm{DM})$ & 27.60 & 22.1 & 27.40 \\
Neutral detergent fiber $(\mathrm{g} / \mathrm{kg} \mathrm{DM})$ & 284.70 & 31.10 & 83.20 \\
Acid detergent fiber $(\mathrm{g} / \mathrm{kg} \mathrm{DM})$ & 32.0 & 286.50 & 251.0 \\
Crude protein $(\mathrm{g} / \mathrm{kg} \mathrm{DM})$ & 126.0 & 51.50 & 120.10 \\
Calcium $(\mathrm{g} / \mathrm{kg}$ DM) & 10.10 & 5.30 & - \\
Phosphorus $(\mathrm{g} / \mathrm{kg} \mathrm{DM})$ & 7.10 & 2.60 & 6.60 \\
Total chlorides $(\mathrm{g} / \mathrm{kg} \mathrm{DM})$ & 5.560 & 3.0 & 11.97 \\
Sodium & 2.83 & 0.8 & 2.82 \\
Potassium & 12.516 & 15.9 & 11.62 \\
Sulfur & 2.168 & 1.9 & 2.93 \\
\hline
\end{tabular}


Table 3 - Levels of milliequivalents for $\mathrm{Na}, \mathrm{K}, \mathrm{Cl}$ and $\mathrm{S}$, and dietary cation-anion balance (DCAB) of concentrates and Tifton hay

\begin{tabular}{lccc}
\hline & $\begin{array}{c}\text { Cationic } \\
\text { concentrate }\end{array}$ & Tifton hay & $\begin{array}{c}\text { Anionic } \\
\text { concentrate }\end{array}$ \\
\hline $\mathrm{Na}(\mathrm{mEq} / 100 \mathrm{~g} \mathrm{DM})$ & 12.29 & 3.48 & 12.25 \\
$\mathrm{~K}(\mathrm{mEq} / 100 \mathrm{~g} \mathrm{DM})$ & 32.09 & 40.77 & 29.80 \\
$\mathrm{Cl}(\mathrm{mEq} / 100 \mathrm{~g} \mathrm{DM})$ & 15.66 & 8.45 & 33.74 \\
$\mathrm{~S}(\mathrm{mEq} / 100 \mathrm{~g} \mathrm{DM})$ & 13.55 & 11.88 & 18.32 \\
$\mathrm{DCAB}(\mathrm{mEq} / 100 \mathrm{~g} \mathrm{DM})$ & +15.2 & +23.9 & -10.0 \\
\hline
\end{tabular}

The twelve animals were divided into two groups; the total experimental period lasted three months, two of which were used for radioactive decontamination (depending on the ${ }^{45} \mathrm{Ca}$ half-life) of animals, and one month for the actual experiment.

The pre-experimental period was 21 days, required for adaptation to the vivarium facility of the Laboratory of Animal Nutrition/CENA. Bulls were housed in $25 \mathrm{~m}^{2}$ masonry pens, cement floor, with wood shaving bedding, feeders and cement trough. Diets were supplied twice a day at 08.00 and $16.00 \mathrm{~h}$. Animals were fed diets at a rate of $2.0 \%$ body weight $/ \mathrm{kg} / \mathrm{animal} / \mathrm{day}$, corresponding to the average intake of $3.64 \mathrm{~kg} \mathrm{diet} /$ animal/day.

During the experimental period (seven days), calves were housed randomly in metabolism cages according to the model adapted from Furtado et al. (2000), receiving the experimental diets and water ad libitum. Two days before the start of the experiment, samples of blood $(4.5 \mathrm{~mL})$ and feces $(200 \mathrm{~g})$ of each animal were collected for analysis of inorganic $\mathrm{P}$ and $\mathrm{Ca}$. Subsequently, $0.5 \mathrm{~mL}$ of a syringe, corresponding to 17.8 and $5.5 \mathrm{MBq} 3{ }^{45} \mathrm{Ca}$ and ${ }^{32} \mathrm{P}$, respectively, were injected in each animal via the right jugular. After injection of radioactive solution, blood samples were collected $(10 \mathrm{~mL})$ via left jugular vein at five minutes and 1, 2, 4, 6, 24, 48, 72, 96, 120 and 144 hours. Feces were collected daily in the morning, 24 hours after radionuclide application until the seventh day, collecting a rate of $5 \%$ of total daily excretion, which was stored in freezer for later analysis. The same procedure adopted for feces was used with urine, with collected samples of $1 \%$ of the total daily volume.

The Nuclear Energy Research Institute (Instituto de Pesquisas Energéticas e Nucleares, IPEN) produced a ${ }^{32} \mathrm{P}\left(\mathrm{Na}_{2} \mathrm{HPO}_{4}\right)$ radioactive solution and the Amersham provided the ${ }^{45} \mathrm{Ca}\left(\mathrm{CaC}_{12}\right)$ radioactive solution. The total solution showed $159 \mathrm{MBq}$ activity, which was prepared from $2.1 \mathrm{~mL}$ of ${ }^{45} \mathrm{Ca}$ loader-free solution added to $1.0 \mathrm{~mL}$ of ${ }^{32} \mathrm{P}$ (sodium phosphate) saline solution and also loaderfree with $50 \mathrm{MBq}$ activity. Both solutions were diluted in $1.4 \mathrm{~mL}$ sterile saline solution of $0.85 \% \mathrm{NaCl}$ totaling
$4.5 \mathrm{~mL}$ solution. The standard solution was prepared by withdrawing a $0.5 \mathrm{~mL}$ aliquot of each radioactive solution, placing them in a $1 \mathrm{~L}$ flask supplemented with distilled water. Subsequently, aliquots of $0.5 \mathrm{~mL}$ were transferred to counting vials, adding $19 \mathrm{~mL}$ of distilled water. Finally, the radioactivity was read in a liquid scintillation spectrometer (Tri-carb TR (PACKARD)) via Cerenkov effect.

The plasma was separated by centrifugation $(3,000 \mathrm{rpm}$, 10 minutes) and, after precipitation with trichloroacetic acid $(10 \%)$, the levels of inorganic phosphorus were determined as described by Fiske and Subbarow (1925) and inorganic calcium by atomic absorption spectrometry (Zagatto et al., 1979). For radioactivity determination, $1 \mathrm{~mL}$ plasma was added to $19 \mathrm{~mL}$ of distilled water in counting bottles. Feces $(1 \mathrm{~g})$ were dried $\left(105{ }^{\circ} \mathrm{C}\right)$ and digested with hydrochloric acid for determination of inorganic phosphorus and calcium by colorimetry using the method of vanadate and ammonium molybdate. One gram of feces was digested in $5 \mathrm{~mL}$ sulfuric acid at 1:1 and the total volume was transferred to counting vials after completing $20 \mathrm{~mL}$ volume. Urine samples were digested in hot hydrochloric acid and cooled to muffle. Ashes were diluted in hydrochloric acid with volume set at $10 \mathrm{~mL}$ volumetric flask according to Morse et al. (1992) to determine inorganic phosphorus and calcium by the method of vanadate and ammonium molybdate. The radioactivity was measured by the Cherenkov effect according to the International Atomic Energy Agency (IAEA, 1979) after adding $1 \mathrm{~mL}$ urine to $19 \mathrm{~mL}$ distilled water in counting bottle.

To evaluate data from endogenous fecal calcium and phosphorus losses, which are used to calculate the true absorption of an element, the specific activities in plasma and feces were determined, calculated as percentage of injected activity per milligram of phosphorus or calcium. Having determined the specific activities in feces, plasma and urine, the metabolism of calcium and phosphorus was determined according to the equations proposed by Lofgreen and Kleiber (1953). The analyzed variables included: endogenous calcium (\%), calcium intake in $\mathrm{mg} / \mathrm{kg}$ BW, calcium availability (\%), calcium excreted in feces in $\mathrm{mg} / \mathrm{kg} \mathrm{BW}$, endogenous calcium in $\mathrm{mg} / \mathrm{kg} \mathrm{BW}$ and true calcium absorption in $\mathrm{mg} / \mathrm{kg}$ BW. The statistical model used was:

$$
\mathrm{Y}_{i j}=\mu+\tau_{i}+\beta_{j}+\varepsilon_{i j}
$$

in which $\mathrm{Y}_{i j}=$ estimated parameter $=$ answer response: calcium metabolism; expressed as amount of feces calcium, amount of endogenous calcium and amount of absorbed calcium; $\mu=$ overall mean; $\tau_{i}=$ fixed effect of a diet (CAT, TFT and ANI); $\beta_{j}=$ fixed effect of the $j$-th block; and $\varepsilon_{i j}=$ 
random error, assuming that $\varepsilon_{i j} \sim \mathrm{Z}\left(0, \sigma^{2}\right)$. All data were analyzed at two different time periods according to the statistical model.

Statistical analysis was performed using the SAS (Statistical Analysis System, version 9.2) software in the GLM procedure. The t-test at 5\% probability was applied for comparison between means.

\section{Results}

Mean values for total calcium intake (Table 4) in the CAT, TFT and ANI diets were 211.19, 82.63 and $182.87 \mathrm{mg} / \mathrm{kg}$ BW $(\mathrm{CV}=9.81 \%)$, respectively. The analysis of variance indicated statistical differences between diets $(\mathrm{P}<0.05)$; the animals that received the CAT diet based on cationic concentrate had the highest calcium intakes. The calcium intake in this study averaged $40.49 \mathrm{~g}$ per day for steers fed the cationic concentrate. The lowest intake achieved with the TFT diet was $15 \mathrm{~g} \mathrm{Ca}$ /day, not reaching the minimum calcium requirements.

The averages for the total calcium excreted in feces in the CAT, TFT and ANI diets were 50.64, 25.90 and $35.98 \mathrm{mg} / \mathrm{kg} \mathrm{BW} /$ day, respectively. The highest excretion was obtained with the CAT diet, based on cationic concentrate.

The ANI diet, based on anionic concentrate, showed higher levels of calcium excretion in feces only in relation to the TFT diet, which despite a high cationic charge $(+23.9$ $\mathrm{mEq} / 100 \mathrm{~g} \mathrm{DM})$, had the lowest calcium intake $(\mathrm{P}<0.05)$.

The endogenous calcium percentage represents the average endogenous fecal loss. The average values of endogenous fecal calcium in diets CAT, TFT and ANI were $55.79,80.16$ and $49.63 \%(\mathrm{CV}=22.05 \%)$, respectively. There was no difference between diets CAT and ANI, but diet TFT, which contained hay exclusively and had the lowest calcium intake obtained in the study, showed statistically the highest amount of endogenous fecal loss $(\mathrm{P}<0.05)$.

The average amount of endogenous calcium in the CAT, TFT and ANI diets were 27.62, 20.56 and $17.92 \mathrm{mg} / \mathrm{kg} \mathrm{BW}$ $(\mathrm{CV}=24.84 \%)$, respectively. Animals that received the ANI diet made from anionic concentrate had less endogenous calcium excretion, not differing from animals fed the TFT diet with lower calcium intake.

The higher endogenous calcium value obtained in the CAT diet (27.62 $\mathrm{mg} \mathrm{Ca} / \mathrm{kg} \mathrm{BW})$ resulted from the higher intake of dietary calcium, not differing from the values obtained with the TFT diet (20.56 mg Ca/ $\mathrm{kg} \mathrm{BW})$. The higher values of fecal endogenous calcium obtained with the TFT diet did not result from the intake of dietary calcium, thus indicating a probable mobilization of body reserves. The TFT diet had higher values of endogenous calcium due to a calcium deficiency condition.

The average values of absorbed calcium in the CAT, TFT and ANI diets were 188.13, 77.23 and $164.88 \mathrm{mg} / \mathrm{kg}$ BW, respectively. Statistical analysis indicated significant differences $(\mathrm{P}<0.05)$ between diets, and the animals that consumed the TFT diet showed the lowest calcium absorption $(77.23 \mathrm{mg} / \mathrm{kg} \mathrm{BW})$. The CAT and ANI diets showed no significant differences in absorption (188.13 and $164.88 \mathrm{mg} / \mathrm{kg} \mathrm{BW}$ ), although the calcium intake presented between these diets was statistically different (211.19 vs. $182 \mathrm{mg} \mathrm{Ca} / \mathrm{kg} \mathrm{BW})$.

The average bioavailability values obtained with diets CAT, TFT and ANI were 89.15, 93.74 and 89.98\% (CV = $4.58 \%$ ), respectively. There was no statistical difference among diets.

\section{Discussion}

Setti (2000) worked with calcium intake values of $82 \mathrm{~g} / \mathrm{cow} /$ day associated with a cationic concentrate and $122 \mathrm{~g} / \mathrm{cow} /$ day for cows receiving an anionic concentrate. The high calcium intake was supplied by the researcher according to a study on lactating cows where nutritional requirements based on milk production were greater. According to NRC (1996), the minimum calcium requirements for growing animals with a daily weight gain of $500 \mathrm{~g}$ is $20 \mathrm{~g} /$ day. The difference in calcium intake between diets CAT, TFT and ANI hampered the interpretation of DCAB effects on the true calcium absorption in endogenous losses and bioavailability.

Table 4 - Mean values of parameters related to calcium (Ca) metabolism

\begin{tabular}{lccc}
\hline Parameter calcium/diet & Cationic concentrate & Tifton hay & Anionic concentrate \\
\hline Ca intake $(\mathrm{mg} / \mathrm{kg} \mathrm{BW} /$ day) & $211.19 \mathrm{a}$ & $82.63 \mathrm{~b}$ & $182.87 \mathrm{c}$ \\
Fecal Ca $(\mathrm{mg} / \mathrm{kg} \mathrm{BW} /$ day $)$ & $50.64 \mathrm{a}$ & $25.90 \mathrm{~b}$ & $35.98 \mathrm{c}$ \\
Endogenous Ca (\%) & $55.79 \mathrm{a}$ & $80.16 \mathrm{~b}$ & $49.63 \mathrm{~b}$ \\
Endogenous Ca (mg/kg BW/day) & $27.62 \mathrm{a}$ & $20.56 \mathrm{ab}$ & $17.92 \mathrm{~b}$ \\
Absorbed Ca (mg/kg BW/day) & $188.13 \mathrm{a}$ & $77.23 \mathrm{~b}$ & $164.88 \mathrm{a}$ \\
Bioavailability $(\%)$ & $89.15 \mathrm{a}$ & $93.74 \mathrm{a}$ & $89.98 \mathrm{a}$
\end{tabular}

Means followed by different letters in the same row differ by the $t$ test $(\mathrm{P}<0.05)$. 
In general, experiments on macromineral metabolism, values of calcium intake and phosphorus show a high correlation with excreted values of the order of $0.93(\mathrm{P}<0.01)$ (Dorigan, 2000). This high correlation may explain the higher values of calcium excreted in feces, since, according to the literature, anionic diets increase calcium excretion in feces and urine (Takagi and Block, 1991). This study showed a significant difference in calcium intake among diets; this difference may have neutralized the possible action of DCAB in the ANI diet $(-10.0 \mathrm{mEq} / 100 \mathrm{~g} \mathrm{DM})$ in increasing levels of calcium excretion.

Endogenous calcium values may result from the loss of calcium from tissues (loss required) and also the removal of excess mineral present in the body. In the TFT diet, higher values of endogenous Ca probably originated from increased calcium mobilization from body reserves due to the disability shown by intake. However, endogenous calcium values in goats also subjected to calcium intake below requirements did not differ in percentage of endogenous fecal calcium (Dorigan, 2000). Few studies have been conducted with findings of endogenous calcium in ruminants, which makes it difficult to compare results.

This numerical approximation of endogenous calcium values between the TFT and ANI diets is due to the high percentage of endogenous calcium found in the feces of animals fed the diet with Tifton hay exclusively.

The negative DCAB $(-10 \mathrm{mEq} / 100 \mathrm{~g} \mathrm{DM})$ calculated for the ANI diet did not increase the excretion of endogenous calcium, and is apparently in agreement with Vagnoni et al. (1998), resulting in lower DM intake and consequently high calcium in the diet.

According to Le Clerk and Block (1989), the addition of anions to the diet does not increase the intestinal calcium absorption. Unfortunately, due to the difference in total calcium intake obtained between diets CAT and ANI, the anion effect on calcium absorption could not be observed in this study. The lower calcium absorption found with the TFT diet was proportional to the lower intake of dietary calcium; the greater level of calcium excreted in feces was possibly caused by mobilization of body reserves.

The bioavailability values found in this study were higher than data obtained by Dorigan (2000), who supplemented basal diets supplied to goats $(69.34 \%)$ with limestone $(0.30 \%)$.

Schonewille et al. (1994) evaluated the apparent absorption of calcium in dairy cows fed anionic and cationic diets and found apparent absorption values of about 9.0 and 3.4\% for anionic and cationic diets, respectively. In the present study, the ANI diet made from anionic concentrate $(\mathrm{DCAB}$ value $=-10 \mathrm{mEq} / 100 \mathrm{~g} \mathrm{DM})$ did not alter the calcium bioavailability.
Takagi and Block (1991) evaluated the negative DCAB effect on the apparent availability of calcium in sheep, and the values obtained with diets containing $0.85 \%$ calcium and $40.95 \mathrm{~g}$ calcium consumed per day did not differ significantly and the apparent calcium availability was 11.18 and $12.11 \%$ for diets containing +28.4 and $-2.7 \mathrm{mEq} / 100 \mathrm{~g}$ DM.

Abu Damir et al. (1991) studied the effect of supplementation of ammonium chloride on the bioavailability of calcium in sheep and found a decrease in calcium availability from 30.98 to $17.33 \%$ in proportion to the replacement of sodium carbonate with ammonium chloride. Still, the figures were lower than those obtained in the present research. The high value of dietary calcium absorption in TFT, the exclusive hay diet, can be explained by reabsorption of endogenous calcium secreted in the digestive system. The data of apparent calcium availability did not alter endogenous levels.

\section{Conclusions}

Based on the isotope dilution technique, the negative dietary cation-anion balance used in this study $(-10.0$ $\mathrm{mEq} / 100 \mathrm{~g} \mathrm{DM})$ does not affect the calcium metabolism, especially endogenous losses and true absorption.

\section{References}

Abu-Damir, H.; Scott, D.; Loverridge, N.; Buchan, W. and Milne, J. 1991. The effects of feeding diets containing either $\mathrm{NaHCO}_{3}$ or $\mathrm{NH}_{4} \mathrm{Cl}$ on indices of bone formation and resorption and on mineral balance in the lamb. Experimental Physiology 76:725-732.

AOAC - Association of Official Analytical Chemists. 1980. Official methods of analysis. 13th ed. AOAC, Arlington, V.A.

Dishington, I. W. 1975. Prevention of milk fever (hypocalcemic paresis puerperalis) by dietary salt supplements. Acta Veterinary Scandinavia 16:503-512.

Dorigan, C. J. 2000. Metabolismo e perda endógena de cálcio em cabritos Saanen. Tese (D.Sc.). Faculdade de Ciências Agrárias e Veterinárias, Universidade Estadual Paulista, Jaboticabal.

Fiske, C. H. and Subbarrow, Y. 1925. The colorimetric determination of phosphorus. Journal Biological Chemistry 66:375-400.

Furtado C. E.; Tosi, H. and Vitti, D. M. S. S. 2000. Gaiola de metabolismo para equinos. Acta Scientiarum 22:813-816.

Hersom, M. J.; Hansen, G. R. and Arthington, J. D. 2010. Effect of dietary cation-anion difference on measures of acid-base physiology and performance in beef cattle. Journal of Animal Science 888:374-382.

Horst, R. L.; Goff, J. P. and Reinhardt, T. A. 1994. Calcium and vitamin $\mathrm{D}$ metabolism in the dairy cow. Journal Dairy Science 77:1936-1951.

IAEA - International Atomic Energy Agency. 1979. Laboratory training manual on the use of nuclear techniques in animal research. IAEA, Vienna. 
Le Clerck, H. and Block, E. 1989. Effects of reducing cation-anion balance for prepartum dairy cows with specific reference to hypocalcemic parturient paresis. Canadian Journal Animal Science 69:41-48.

Lofgreen, G. P. and Kleiber, M. 1953. The availability of the phosphorus in alfafa hay. Journal of Animal Science 12:366-371.

Morse, D.; Head, H. H.; Wilcox, C. J.; van Horn, H. H.; Hissen, C. D. and Harris Jr., B. 1992. Effects of concentration of dietary phosphorus on amount and route of excretion. Journal of Dairy Science 75:3039-3949.

NRC - National Research Council. 1996. Nutrient requirements of beef cattle. 7th ed. National Academy Press, Washington, D.C.

Ross, J. G.; Spears, J. W. and Garlich, J. D. 1994. Dietary electrolyte balance effects on performance and metabolic characteristics in growing steers. Journal of Animal Science 74:1842-1848.

Salles, M. S. V.; Zanetti, M. A.; Negrão, J. A.; Salles, F. A.; Ribeiro, T. M. C.; Saran Netto, A. and Del Claro, G. R. 2012. Metabolic changes in ruminant calves fed cation-anion diets with diferent proportions of roughage and concentrate. Revista Brasileira de Zootecnia 41:414-420.

Schonewille, J. T.; Van't-Klooster, A.T.; Dirkzwager, A. and Beynen, A. C. 1994. Stimulatory effect an anion (Chloride)-rich ration on apparent calcium absorption in dairy cows. Livestock Production Science 40:233-240.

Setti, M. C.; Schalch, E. and Zanetti, M. A. 1998. Estudo do balanço cátion-aniônico da dieta no desempenho de vacas holandesas. Revista Brasileira de Zootecnia 27:1241-1247.

Setti, M. C. 2000. Parâmetros metabólicos e balanço cátion-aniônico da dieta (BCAD) para vacas da raça holandesa. Tese (D.Sc.). Faculdade de Ciências Agrárias e Veterinárias, Universidade Estadual Paulista, Jaboticabal.

Spears, J. W. 1996. Beef nutrition in the 21st century. Animal Feed Science and Technology 58:29-35.

Takagi, H. and Block, E. 1991. Effects of manipulation dietary cationanion balance on macromineral balance in sheep. Journal Dairy Science 74:4202-4214.

Vagnoni, D. B. and Oetzel, G. R. 1998. Effects of dietary cation-anion differnce on the acid-base status of dry cows. Journal of Dairy Science 81:1643-1652.

Zagatto, E. A. G.; Krug, F. J.; Bergamin Filho, H.; Jorgensen, S. S. and Reis, B. F. 1979. Merzing in flow injection analysis. Part 2. Determination of calcium, magnesium and potassium in plant material by flow injection atomic and flame emission spectrometry. Analytica Chimica Acta 104:279-284. 